\title{
河川環境改善のための底生動物生息の物理、 飰環境要因分析 \\ RELATIONSHIP BETWEEN HABITAT OF AQUATIC ORGANISMS AND PHYSICAL, RESOURCES FACTORS FOR IMPROVEMENT OF RIVER ENVIRONMENT
}

\author{
矢部浩規 1 ・ 中津川誠 2 \\ Hiroki YABE, and Makoto NAKATSUGAWA \\ 1正会員 博 (工学) (独)北海道開発土木研究所 ( \\ 2 正会員 博(工学) (独)北海道開発土木研究所 (干062-8602 札幌市豊平区平岸1条3丁目)
}

\begin{abstract}
River improvement and maintenance works can play an important role in conserving rivers and restoring them to a more natural state. This paper focuses on aquatic organisms (specifically, benthic animals) as indicators of river conditions, toward clarifying the relationship between inhabitation by these animals and the physical conditions of a river channel (flow velocity, water depth, bottom materials) and the food environment (i.e., periphyton and particulate organic matter). The relationship was examined by comparing pools and riffles in various types of river channels, such as those with and without river improvement works.

The examination found that improved sections have less storage of organic matter than unimproved sections have. We also confirmed our findings on restoring a river to its natural state by varying the physical conditions and food environment in the improved section.
\end{abstract}

Key Words : Benthic animals, river environment, physical conditions, food environment, organic matter

\section{1. 背景と目的}

上流域から下流域まで連続的に生態的な影響が及ぶと される河川生態系を保全する上で、特に急峻で流れが速 い我が国の河川では、上流域での有機物の供給や帯留が 重要である ${ }^{1)}$ と言われている.しかし、流域の土地利用 変化や河川改修等による河畔林、瀬、淵などの減少に よって、河川水中での有機物量や滞留状況の変化が指摘 されている.このような河川環境の変化は、魚類、底生 動物や他の生物の生息環境に影響を及ぼし、河川の自然 度、健全性が損なわれる懸念がある。

底生動物の生息状況は、そのデー夕収集が比較的容易 で、分布の広がり、種類数から、河川水質の評価に利用 されている他、河川の地点や区間の状況、瀬、淵の河床 単位（ユニット）区間レベル以下の河川環境を反映する ことが知られている. 近年では、堰上下流での堆積環境 の違いを、群集（個体数、種類数など）を用いた指数に よって評価している例や、河川改修工事、流域の変化に 伴う環境変化を群集の変化によって把握しようとする研

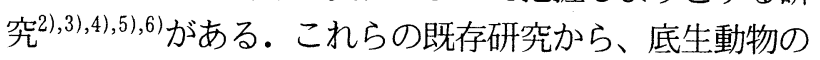
生息環境要因として流速、河床材料の他、有機物量など
が影響していることが明らかになってきたが、底生動物 を指標とした評価法は確立されていない.また、底生動 物レベルの生息環境の保全は、魚類、付着藻類、細菌類 レベルの生息環境の保全に結びつくと考えられる.その ため、本研究では、底生動物の生息状況やその生息環境 要因によって河川環境を評価し、河川環境を改善するた めの知見を得ることを目的としている。

対象河川を、上流域に改修区間と自然の未改修区間が 存在する、北海道札幌市を流れる厚別川とした. 改修区 間と自然区間で底生動物の生息状況と生息環境要因との 比較を行い、底生動物の生息環境の要因分析、物理環境

（流速、水深、河床材料、浮石）と䬣環境（粒状有機物、 付着藻類）との関係分析から、河川の自然再生、環境改 善にアプローチするものである.

次に、本研究によって得られた底生動物群集による河 道状況の評価を適用して、改修区間において人工的に物 理環境、慨環境を変化させる実験を実施し、河川環境の 改善効果の検証を行った. 自然再生事業による効果の把 握がはじまりつつあるが、このように実験的に河道構造 を変化させ、底生動物群集の生息状況の変化を把握した 事例》は我が国ではみあたらない。 


\section{2. 調査方法、位置}

対象区間の河道特性は、未改修、改修区間ともにセ グメントはM（山間部）、平均粒径は 5 ～10cm 程度で 砂州はみられない。 未改修区間は、自然な状態で蛇行を 繰り返し、縦断勾配は約 1/100、調査時の水面幅は 3 $5 \mathrm{~m}$ であった。一方、改修区間では 20〜30 年前に工事 が実施されている. 延長距離が $3200 \mathrm{~m}$ から $2800 \mathrm{~m} へ と$ 直線化、線形改良がなされ、数 $100 \mathrm{~m}$ 間隔で設けられた 落差工(高さ約 $1 \mathrm{~m}$ )により紩断勾配は約 $1 / 120$ から 1/180 へ緩和されている. また、河岸から河床に連節ブ ロックが設置されており、ブロックの垂れ部が両岸各 3 $\mathrm{m}$ 、中央の碟河床部分の幅 $2 \mathrm{~m}$ とあわせて河床幅は $8 \mathrm{~m}$ 程である. 未改修区間より $5 \mathrm{~km}$ 程下流に位置し、その 間に小さな沢が 2 本あるが、規模が小さく影響は及ぼし ていない. 河畔林は未改修区間で広葉樹、針葉樹、改修 区間ではヤナギ類が優占している。

調查は対象河川において大半の底生動物が幼虫初期に あたる2003年10月中旬〜11月上旬に行った。対象区間を 早瀬、淵に分類(Bissonによる)し、1 ユニットにトラン セクト（横断線）を 5 本、さらに 1 トランセクトに4側 点の計20箇所の計測地点を設定した (図-1). 改修区 間では直線的で瀬状の流れが続くが、落差工下流の水吒 き部のみが水深40～ $50 \mathrm{~cm}$ と深く、淵状の形態を呈してい るため、淵とした。 その状況は基部にコンクリート床版 がありその上に碟が20cmほど堆積した状態で常に流水の 影響を受け不安定な状態にあった。底生動物は、1 1 工 ニットあたり早瀬において 4 サンプル、淵では 6 サンプ ルを、サーバーネット $(25 \mathrm{~cm} \times 25 \mathrm{~cm})$ を使用して採集 した.そして、0.5 mm以上の大きさの底生動物を対象に、 属または種レベルまで同定を行った。

有機物は、底牛動物採取地点と同地点で $1 \sim 20 \mathrm{~mm}$ の粗 粒有機物(Coarse Particulate Organic Matter: 以下CPOM)、 $1 \mathrm{~mm}$ 以下の細粒有機物（Fine Particulate Organic Matter : 以 下FPOM）に分けて強熱減量を計測した. 付着藻類も同 様の䇢所の碟 $(5 \mathrm{~cm} \times 5 \mathrm{~cm})$ で採取した.

物理環境は、1 計測地点をさらに図－1のように 25 等分し、流速、水深、浮き石率は 1 計測地点あたり 5 点、 河床材料は25点で計測、平均して、1ユニットあたり 20 箇所データを収集している. 流速の計測は、1箇所に つき 2 割、8 割水深で電磁流速計により 5 秒間の平均値 を測定した．浮き石率の計測は、 $10 \mathrm{~cm} \times 10 \mathrm{~cm}$ 枠内で採取 した最大粒径の石の状態（色や付着藻類の付き方）から、 4 分類（1:25\%以下、2: 25〜50\%、3: 50〜 75\%、4: 75 〜100\%）を目視で判断した。また、河床材料の計測は 対象区間では砂分が少なく碟で構成され、こぶし大の磁 も多いことから、粒度分析の必要性は低く目視で分類の 判断が十分可能であった。そして、底生動物の生息関係 を明確化するため、Wentworth基準を拡張して 8 分類 （1:岩盤、2: $<\phi 2 \mathrm{~mm} 、 3: \phi 2 \sim 16 \mathrm{~mm} 、 4: \not 16 \sim 32 \mathrm{~mm}$ 、
5: $\phi 32 \sim 64 \mathrm{~mm} 、 6: \phi 64 \sim 128 \mathrm{~mm} 、 7: \not 128 \sim 256 \mathrm{~mm} 、 8: \phi$ $256 \mathrm{~mm}<)$ に細か人分けている. その他、河川水位、水 温、気温、水質調査等を実施した。

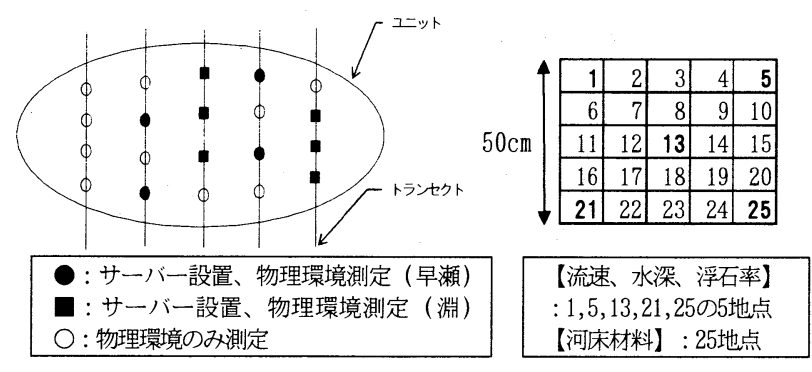

図-1 底生動物(有機物)、物理環境計測地点と調查方法

\section{3. 調査分析結果}

\section{（1）底生動物生息のユニットスケール分析}

厚別川における未改修と改修区間における比較を行う. それぞれの区間における河床単位 (ユニット) 別に、水 深、流速等河道の物理環境、FPOM、CPOM等䬣環境、 底生動物の群集（総個体数、分類群数（taxa数）、多様 度、優占種）の計測結果を表 - 1 に示す．底生動物は、 採餌方法（摂食機能群）によって分類している．粗大粒 状有機物(落葉落枝)をそのまま食べる破砕食者 (shredder:sh)、付着藻類をはがし刚り取って食べるはぎ 採り食者(scraper:sc)、微細粒状有機物を利用する採集食 者 (collector)、他の昆虫を食べる捕食者(predator:pr)に分 類した。採集食者は $\operatorname{cg}($ 沈殿する有機物を拾う)とcf（水 中の愳濁有機物を網でこし取り食べる)に分けている.

表-1 底生動物、物理・餌環境計測結果

\begin{tabular}{|c|c|c|c|c|}
\hline & \multicolumn{2}{|c|}{ 改修区間 } & \multicolumn{2}{|c|}{ 末改修自然区間 } \\
\hline 要因 & 臣瀬 $(\mathrm{n}=3)$ & 淵 $(\mathrm{n}=3)$ & 早瀬 $(n=3)$ & 淵 $(n=3)$ \\
\hline 水深 $(\mathrm{cm})$ & 28.6 & 41.8 & 23.4 & 42.7 \\
\hline 流速 $(\mathrm{cm} / \mathrm{s})$ & 76.1 & 37.8 & 64.2 & 45.9 \\
\hline 河床材の大きさ & 6.3 & 4.8 & 5.8 & 5.3 \\
\hline 浮石率 & 2.5 & 3.1 & 2.2 & 3.3 \\
\hline FPOM $\left(\mathrm{g} / \mathrm{m}^{2}\right)$ & 0.26 & 0.40 & 0.46 & 0.43 \\
\hline $\operatorname{CPOM}\left(\mathrm{g} / \mathrm{m}^{2}\right)$ & 1.93 & 1.21 & 3.86 & 2.87 \\
\hline タロフイル $\mathrm{a}(\mu \mathrm{g} / \mathrm{cm}$ & 0.10 & 0.15 & 0.50 & 0.45 \\
\hline 総個体数 $\left(/ \mathrm{m}^{2}\right)$ & 1590.7 & 1260.0 & 1704.0 & 1438.2 \\
\hline 分類群数 & 12.8 & 10.2 & 19.2 & 18.9 \\
\hline 多様度(shannon) & 1.6 & 1.2 & 2.2 & 2.1 \\
\hline 優占種(\%) & $\begin{array}{l}\text { Rh }(\mathrm{cg} \cdot \mathrm{sc}) 45 \% \\
\mathrm{Gl}(\mathrm{sc}) 14 \% \\
\operatorname{Am}(\mathrm{sh}) 6 \%\end{array}$ & $\begin{array}{l}\text { Rh(cg'sc)64\% } \\
\text { Gl(sc)7\% } \\
\mathrm{Pa}(\mathrm{cg}) 6 \%\end{array}$ & 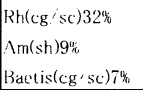 & $\begin{array}{l}\mathrm{Rh}(\mathrm{cg} / \mathrm{sc}) 27 \% \\
\mathrm{Am}(\mathrm{sh}))^{4} \\
\mathrm{Ap}(\mathrm{cg} / \mathrm{sc}) 9 \%\end{array}$ \\
\hline 備考（属名） & 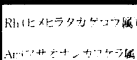 & Ba (コカゲロウ倔) & 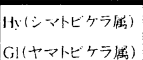 & 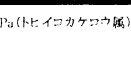 \\
\hline
\end{tabular}

以上のデータから、河道（自然の未改修と改修区間） 河床単位 (早瀬と淵) の間での違いを比較、検討 ${ }^{8}$ する ため、二元配置分散分析を行った. 個体数、分類群数、 多様度の底生動物群集の違いに対する分析を各々行う。 底生動物群集、物理環境（流速、水深等）、䬺環境（有 機物量等) は河床単位ごとの平均值を用い、また、等分 散性を仮定するため、全変数について対数変換した。そ の結果、総個体数は、両区間、早瀬、淵ともに有意な違 

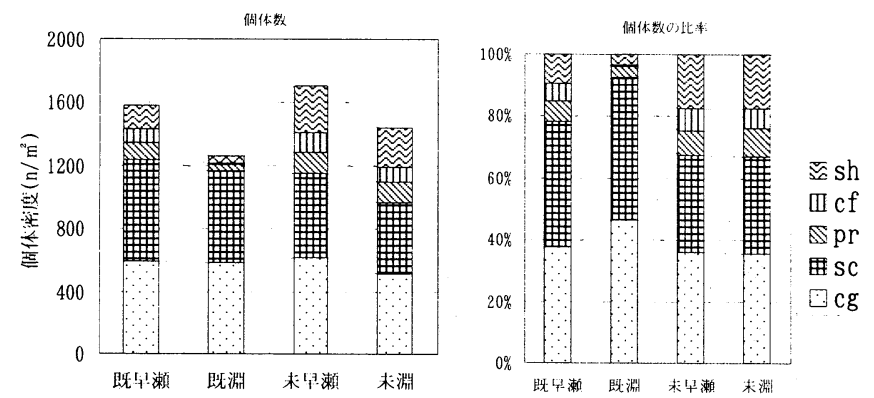

図-2 河道、河床単位別の個体数と昹食機能群分類
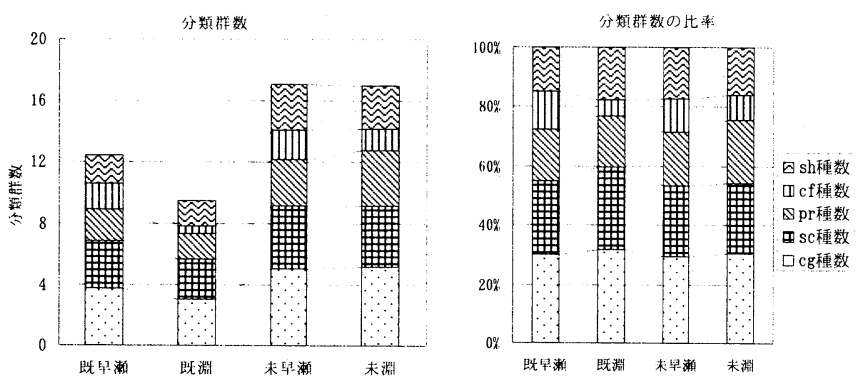

図 - 3 河道、河床単位別の分類群数と摂食機能群分類

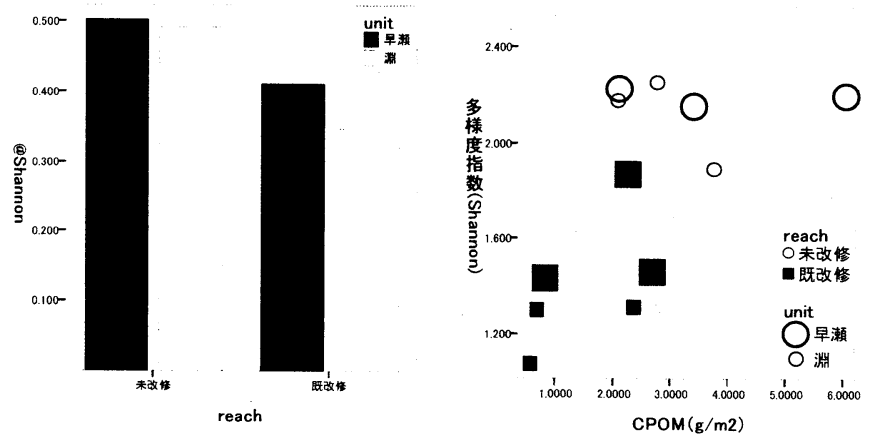

図 - 4 河道、河床単位別多様度とCPOMとの相関関係

いはなかった. 分類群数、多様度は、未改修区間が改修 区間より有意に大きく、多様度については早瀬のほうが 淵より有意に大きかった(有意水準 $\mathrm{p}<0.05)$. 河道と河床 単位では父互作用は認められなかった。

餌環境要因や物理環境要因について、河道、河床単位 との間での違いについても同様に分散分析を行っている. 河道区間での違いが表れた要因はCPOMであり、自然の 未改修区間は既改修区間に比べ有意に大きかった。 FPOM、クロロフィルaでは違いは表れず、また、物理 環境要因においても浮石率河床材の大きさの分散を除 き、流速や水深などに違いは認められなかった.

表 - 1 にある個体数からの優占種では、自然の未改修 区間では第 2 優占種に破砕食者（sh）が確認されている. 捸食機能群における個体数、分類群数とそれらの比率を 図- 2 と図-3に示すが、破砕食者の個体数及びその比 率については、自然の未改修区間が既改修区間に比べ多 いことがわかる．また、各摂食機能群について、河道、
河床単位との間での違いを分散分析した結果からも、 破砕食者（sh）のみが、自然の未改修区間で有意に大き かった. 分類群数については、差はみられなかった。

底生動物群集に影響を与えている物理環境要因、餌 環境要因 (有機物量等) との関係把握のために、自然

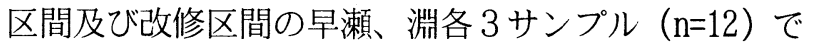
相関分析を行った。その結果、多様度に関してCPOMの みに正の相関が認められた $(r=0.710, p<0.05 、$ 図 - 4). その他、河床材の大きさが、分類群数、多様度指数と 正の相関を示した $(r=0.665: r=0.658, p<0.05)$.

（2）サブユニットスケール分析

さらに、底生動物をサンプリングした地点データの みを用いたサブユニットスケールでの分析を行った。 河道、河床単位ごとに、底生動物群集（個体数、分類 群数、多様度）と物理環境要因、餌環境要因との単相 関分析結果が図 - 5である.

その結果、早瀬においては、自然の未改修区間で底 生動物群集とCPOM、FPOMとの間で正の相関がある。 CPOMは多様度と正の相関があった。しかし、改修区 間ではCPOM、FPOMとの相関は認められず、底生動 物群集とクロロフィルaとの間で正の相関関係があった. 物理環境要因については、自然区間ではほとんど相関 関係が認女られなかった。改修区間の早瀬では、流速 と負の相関関係があり、流速が大きい箇所では底生動 物の個体数、分類群数が減少している. 浮き石率と負 の相関関係にあり、河床の擋乱が大きく底生動物の生 息にとってあまりょい状況とはいえない．その他、生 息面積が増える河床材の大きさ要因と正の相関関係が 認められた。

淵においては、自然区間では相関関係は認められず、 改修区間でCPOMが底生動物群集（個体数、分類群
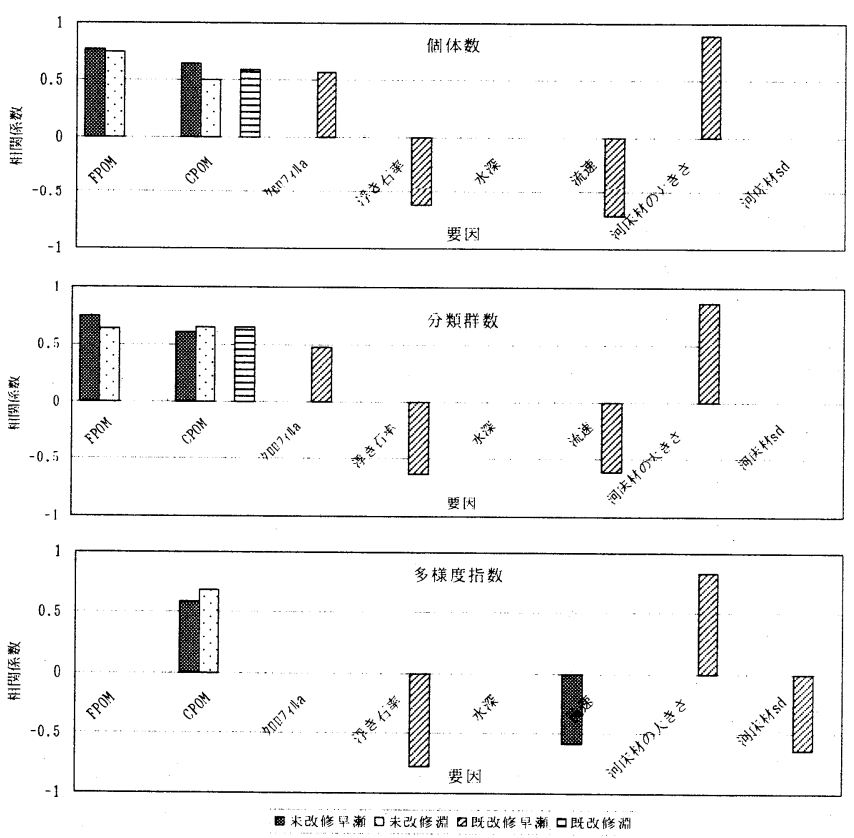

図－5 底生動物群集と生息環境要因の相関分析 
数）と正の相関関係が認められのみであった。淵のなか でのCPOMの堆積状況によって底生動物の生息に影響し ていることが考えられる。

以上から、改修区間の早瀬ではCPOMの堆積、供給が 少ないため、餌環境要因として付着藻類のみ影響し、物 理環境要因が生息状況に影響を及ぼしていると考えられ る. 自然区間では改修区間に比べCPOMが堆積し、物理 環境要因が影響していないことから、調査が行われた秋 季ではCPOMが生息要因として重要であることが確認さ れ、両区間での違いが明確となった。

また、攝食機能群毎に各々の群集と生息環境要因の相 関分析も行った。CPOMを利用する破砕食者の個体数は、 未改修区間の早瀬において、CPOMと正の相関にあるが、 改修区間では認められなかった。FPOMを利用する採集 食者は、未改修区間の早瀬でCPOM 、FPOMと正の相 関がある. 付着藻類をはがすはぎ採り食者は、改修区間 の淵でクロロフィルaと正の相関があった.

\section{4. 物理環境要因と慨環境要因の関係分析}

\section{(1) 物理環境と飳環境の関係}

底生動物群集を、物理環境、餌環境要因から予測する ことが可能であれば、群集と要因間の関係はもとより要 因間の相互の関係が明確になる.特に、河川環境を改善 するための改修方法に関する知見を得るためには、どの ような生息環境（物理環境、餌環境）を提供すべきか、 河川環境を改善した場合の群集を予測しつつ、具体的な 工法に結びつく基準值等を明らかにする必要がある. 前 述の底生動物群集と生息環境要因の相関分析から、物理 環境と慨環境の 2 要因との関係が重要であると考えられ る. 底生動物群集を予測する回帰式の構築はサンプル数 が少なく難しかった。そこで、本研究は物理環境要因と 餌環境要因の関係を把握する．自然区間、改修区間とも 主に早瀬において群集と相関関係が表れたため、早瀬を 対象に分析を行う。

はじめに、物理環境要因（流速、水深など）と䬣環境 （FPOM、CPOM、付着藻類）の関係を把握するため、 自然区間と改修区間の早瀬計12地点で相関分析を行った。

自然の未改修区間の早瀬では、水深とCPOMに負の相 関関係 $(r=-0.69, \mathrm{p}<0.05)$ 、河床材の大きさとFPOMに 負の相関関係 $(r=-0.58, \mathrm{p}<0.05)$ 、浮石率とCPOMに正 の相関関係 $(\mathrm{r}=0.639, \mathrm{p}<0.05)$ があった. 水深が浅く、 浮石率が大きいほど粗粒有機物が堆積しやすい、また、 河床材が大きい箇所では細粒有機物が入りにくく堆積し づらい状況と考えられる。

一方、改修区間の早瀬では流速と餌環境要因のすべて で負の相関関係であった。流速とCPOM（r=$0.612, \mathrm{p}<0.05)$ 、流速と FPOM $(\mathrm{r}=-0.502, \mathrm{p}<0.05)$ で あり、クロロフィル $\mathrm{a}$ も流速と負の相関関係 $(\mathrm{r}=-$ $0.489, \mathrm{p}<0.05 ）$ となっている. 流速が大きい箇所ほど有
機物が堆積しづらく、付着藻類も減少しており、改修区 間では有機物があまり滞留せず下流へ流されていると考 えられ、生息環境要因分析結果とも一致する。

\section{( 2 ）正準相関分析}

物理環境要因（水深、流速他）と䬣環境要因（FPOM、 CPOM他）相互の関係を把握するため、本研究では、正 準相関分析 (CCA) を自然区間と改修区間の早瀬におい て適用する. 正準相関分析とは、2組の変量間の相関係 数を把握する際、それを容易にする分析方法である. 本 研究では、物理環境要因と餌環境要因の 2 組にわけ、そ れぞれの合成変量を作って、これら合成変量間の相関関 係が最大となるよう係数（正準変量）を定める。このよ うな条件で、有意な変数を入れ替え河床単位別の自然区 間、改修区間を対象範囲として分析した。

改修、自然区間を含む早瀬を対象にした場合の、正準 相関係数が最大となった結果を図 - 6 に示す. 厚別川の 早瀬では、物理環境のうち、水深、流速が小さく、それ らの分散が大きい、そして、河床材料の大きさ、浮石率 が大きいほど、䬣環境のCPOM、クロロフィルaが多く、 FPOMが小さくなる相関関係が表れた。早瀬において、 水深、流速が小さく、かつそれらの分散が大きい複雑な 流況で、河床材料の大きさが大きく、浮石率が大きいほ ど、CPOMが堆積しやすく、付着藻類が増加しやすい河 道構造となっているという関係を表している．淵におい ても同様の分析を行ったが、明確な関係は得られなかっ た.

図 - 6の餌環境要因軸（AXIS 1) は、值が大きくな AXIS 2

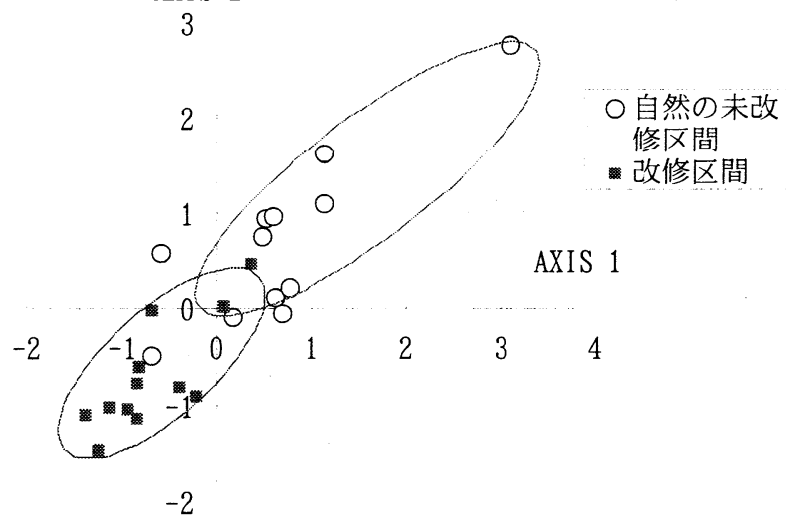

\begin{tabular}{|c|c|c|c|c|}
\hline \multicolumn{2}{|c|}{ 第 1 正準相関係数 } & 0.902 & $\chi$ 2-test(p值) & $\begin{array}{c}45.83 \\
(0.001)\end{array}$ \\
\hline 変数 & $\mathrm{FPOM}(<1 \mathrm{~mm})$ & $\mathrm{CPOM}(1-20 \mathrm{~mm})$ & クロロフィルa & \\
\hline \multirow[t]{2}{*}{$\begin{array}{l}\text { 正準負荷量 } \\
\text { (重み係数) }\end{array}$} & -0.1684 & 0.5406 & 0.7693 & \\
\hline & \multicolumn{4}{|c|}{ Axis2 } \\
\hline 変数 & 浮石率 & 水深 & 流速 & 河床材料 \\
\hline 正準負荷量 & 0.1131 & -0.7103 & -0.3175 & 0.1483 \\
\hline 変数 & & 水深(標準偏差) & 流速(標準偏差) & $\begin{array}{l}\text { 床材料(標準 } \\
\text { 偏差) }\end{array}$ \\
\hline 正準負荷量 & & 0.3228 & 0.2328 & -0.0112 \\
\hline
\end{tabular}

図 - 6 物理環境と餌環境要因分析結果 (CCA) 
るほどCPOMとクロロフィルaが多く、値が小さくなる ほどFPOMが相対的に多いことを示している。一方、物 理環境要因軸（AXIS 2) は、值が大きいほど、水深、 流速が小さく、その分散が大きく、河床材料の大きさ、 浮石率が大きくなる．自然の未改修区間と改修区間をプ ロットすると、自然区間は右上方に、改修区間は左下方 に位置することがわかる.このように、物理環境と䭒環 境の関係から自然区間、未改修区間を特徵づけることが 可能となった.

改修区間の瀬を自然区間の物理環境及び飭環境に近づ けるためには、物理的要因の軸、䭒環境要因の軸の值が 小さいため、その值を増加させる方向に物理環境、餌環 境要因を変化させればよいと考えられる. 河床材料の大 きさ、浮石率は改修区間でやや大きいが、両区間で大き な違いはみられず、係数も小さい。そのため、水深、流 速要因が物理環境要因軸の值に大きく影響している。一 方、䭒環境のすべての要因において自然区間の方が改修 区間より多い。特にCPOM、クロロフィルaが多く、係 数も大きいため、これらの要因が䬶環境要因軸に大きく 影響している.したがって、各々の要因の軸に大きな影 響を及ぼしている水深、流速を減少させ、CPOM、クロ ロフィルaを増加させることによって河川環境の改善が 図られることが予想された。

\section{5. 改修区間（早瀬）における環境改善実験}

以上の分析結果から得られた知見から、本研究では、 人工的に水深、流速の減少と、CPOMの堆積量を増加さ せる実験を、改修区間の早瀬において実施し、底生動物 群集の変化を把握することとした。

土のうによる水制工を用いて、流速を遅くさせる箇所 を設定し、それに伴う河床堆積によって水深が減少する ことを期待した。また、䬣環境要因としてCPOM等が堆 積しやすい環境を、鉄ピンを設置して人工的に改善した. 2003年10月中旬に図-7に示すような4つの実験区を設 定し、物理環境や有機物量等の餌環境を変化させること 平面図
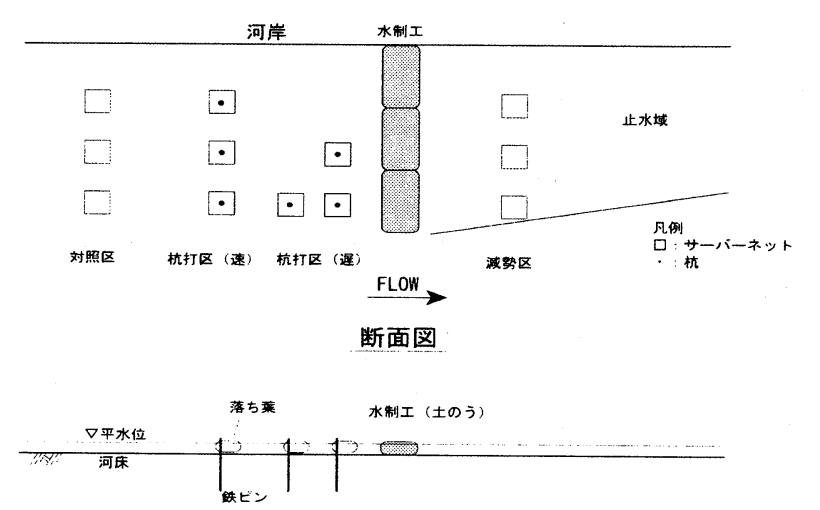

図-7 改修区間 (早瀬) の河川環境改善実験
表 - 2 物理、䭒環境の変化と底生動物群集の変化

\begin{tabular}{|c|c|c|c|c|c|c|c|c|}
\hline \multirow{2}{*}{ 要因 } & \multicolumn{2}{|c|}{ 刘照区 } & \multicolumn{2}{|c|}{ 杭打区(速) } & \multicolumn{2}{|c|}{ 杭打区(晕) } & \multicolumn{2}{|c|}{ 減勢区 } \\
\hline & 事前 $n=3$ & 事後 $n=3$ & 事前 $n=3$ & 事後 $n=3$ & 事前 $n=3$ & 事後 $n=3$ & 事前 $n=3$ & 事後n $=3$ \\
\hline 水深 $(\mathrm{cm})$ & 20.7 & 17.9 & 20.7 & $\overline{14.3}$ & 17.0 & 12.9 & 16.8 & 8.7 \\
\hline $8(\mathrm{~cm} / \mathrm{s})$ & 62.2 & 56.8 & 60.3 & 39.1 & 46.5 & 19.2 & 57.7 & 29.2 \\
\hline 河本材の & & 4.6 & & 15 & & & 4.9 & 29 \\
\hline$\tau$ & 4. & & 4.0 & 3.1 & 4.0 & 3.3 & 4.0 & 2.0 \\
\hline $\mathrm{FPOM}(\mathrm{g} / \mathrm{m}$ & 0.4 & 1.27 & 0.32 & 5.11 & 0.31 & 5.1 & .84 & 0.56 \\
\hline $\mathrm{CPOM}(\mathrm{g} /$ & 3.21 & 08 & 3.53 & 18.79 & 3.49 & 32.78 & 6.27 & 2.41 \\
\hline מ口าイルa & & & 0.07 & 2.46 & 14 & 1.05 & 0.46 & 2.27 \\
\hline 総個体数 $\left(1 / \mathrm{m}^{2}\right)$ & 5594.7 & 2912.0 & 53600.0 & 12453.3 & 3904.0 & 9584.0 & 7264.0 & 3232.0 \\
\hline 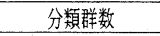 & 22.0 & 22.3 & 25.7 & 46.3 & 23.7 & 39.0 & 27.3 & 21.0 \\
\hline 多様度(shan & 1.3 & 2.1 & 1.4 & 2.6 & 1.7 & 2.4 & 1.7 & 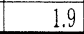 \\
\hline & & hicg scl)275s & sti70\% & & $654^{4}$ & & $45^{6}$ & \\
\hline 優占種( & & (c) $16^{4}$ & & scill 4 & Gilscr) 18\% & Pát(g) 15! & . & \\
\hline & & & & & & & ack scle & \\
\hline (禹保 & & & & & & & & \\
\hline
\end{tabular}

によって底生動物群集に与える影響を検証する．参照区 として、水制工や鉄ピンの影響を受けないサイト（対照 区）を設けた。その下流に、鉄ピンを打ち込み、落ち葉 の集積状況を変化させ、水制工から離れた流速が速い

（遅くならない）サイト（杭打区（速））、水制工に近 く、流速が遅いサイト（杭打区（遅））、水制工を設け ることによって、物理環境を変化させるサイト（減勢 区）を設定した.

事前調查を行った後の約 1 月後の 11 月下旬に事後調査 を実施し、事前、事後調査とも各サイト 3 サンプルの計 12地点で、底生動物、有機物量、付着藻類の採集、物理 環境を計測した（表－2）。物理環境について、流速は 杭打区（遅）で最も小さくなり、減勢区、杭打区（速） の順に小さい，水深も小さくなり、減勢区、杭打区

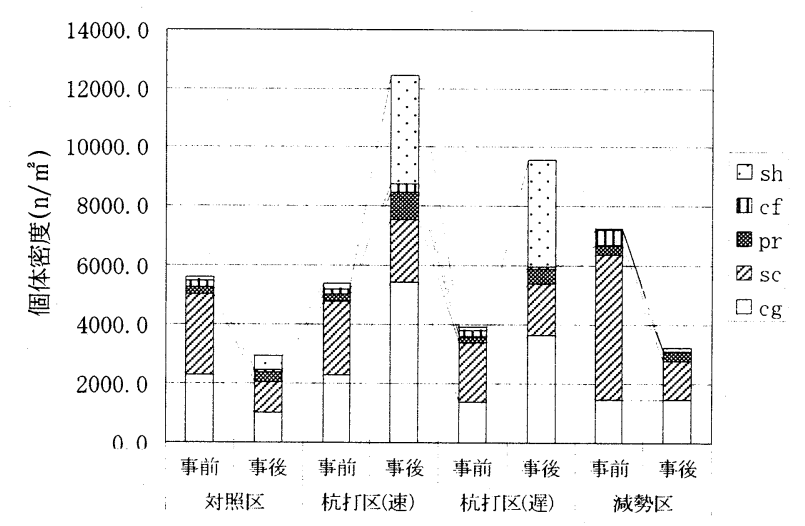

図-8 各サイトの個体数の変化

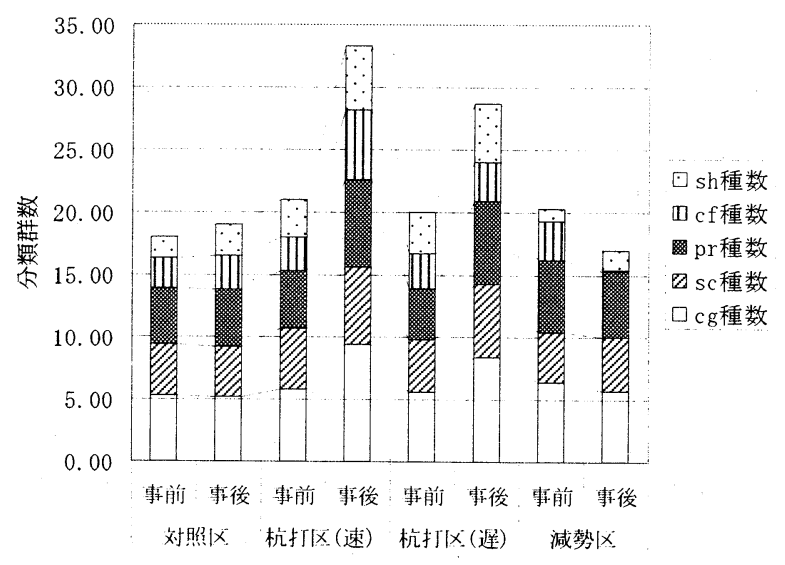

図-9 各サイトの分類群数の変化 
（遅）、杭打区（速）の順となった．なお、対照区にお いても流速、水深は小さくなっていた。分散については、 流速、水深ともに大きくなったのは杭打区（遅）で、共 にやや減少したのが杭打区（速）であり、減勢区は水深 が小さく、流速が大きくなった. 河床材の大きさは、減 勢区、杭打区（遅）で減少し、杭打区（速）、対照区で も若干減少した。浮石率は減勢区で半減し、杭打区（速、 遅）でも減少している. 飭環境は、CPOM、FPOMが杭 打区（速、遅）で大幅に増加し、対照区で増加している 一方、減勢区では減少した。付着藻類については全地点 で増加した. 以上から、杭打区、特に杭打ち区（遅）サ イトは、自然の未改修区間に近い物理、餌環境に変化し たと考えられる.減勢区は、物理環境は改善されたが飭 環境については改善されていないサイトといえる.

底生動物群集の結果（図－8、9）から、個体数は、 対照区及び減勢区では減少したが、杭打区（速、遅）で は増加している. 分類群数は、対照区では変化はなく、 減勢区で減少している一方、杭打区（速、遅）では 2 倍 近く増加している，摂食機能群からは、対照区で、はぎ 採り食者、採集食者の個体数が減少している.破砕食者 は個体数、分類群数が若干増加している。杭打区では、 破确食者の個体数、分類群数が急激に増加し、採集食者、 捕食者の個体数、分類群数も増加している. その結果、 はぎ採り食者の比率が減少している，減勢区では、はぎ 採り者の個体数が激减し採集食者の比率が高まったが、 破砕食者は確認されなかった. 多様度指数は、減勢区で 増加割合は若干低いが全地点で増加している。

減勢区では、物理環境は改善されたが、水制工により 落葉等有機物の供給がさえぎられ、CPOMは堆積しな かった。そのため、底生動物の生息に影響を及ぼしたと は言えない状況である. 杭打区（遅）は、杭打区（速） に比べ、物理、䶿環境が改善され、底生動物群集も増加 することが予想されたが、違いは明確に表れず、逆に杭 打区（速）がやや増加傾向にあった. 以上から、秋季の 改修区間の早瀬において、底生動物の生息にとって物理 環境ではなく、饂環境が制限要因となっており、慨環境 の改善、すなわち有機物の滞留、堆積状況を改善、促進 させる物理環境を提供することで改修区間の環境改善が 可能であることが検証できた.

対照区と比較すると、杭打ち区及ひ減勢区全体として 群集がどのように変化したかについては、個体密度、分 類群数は増加し、多様度は若干増加する. 実験区より上 下流区間での影響範囲は把握していないが、少なくとも 実験区での河川環境は改善されたと考えられる.

\section{6. おわりに}

本研究によって、自然区間と改修区間の早瀬では、底 生動物の生息環境要因が異なっていること、生息環境要 因を水深、流速等物理環境要因と有機物量等饂環境要因
に分けてこれらの関係を把握し、その関係から自然区間 と改修区間の河川環境を特徴づけた。次に、実際に改修 区間の早瀬において自然区間に近づけるための環境改善 実験を有機物量、流速等の生息要因を変化させて実施し、 底生動物群集の変化からその方法の有効性を検証した。

本研究は底生動物の生息環境要因を利用し河川環境を 簡易に評価、把握して工学的利用を目指している. 今回 の調査実施時期である底生動物が生まれて間もない10 11月の時期と、さらに今後、冬〜春にかけて成長し羽化 する直前の $4 \sim 5$ 月の時期を調査し、計 2 季からの環境 評価を考えている．底生動物が羽化する時期は対象河川 で出現する種全般でみた場合、融雪出水以降が主要な時 期である.しかし、種によっては若干時期が異なり、生 活史が異なる場合の調査、評価方法や、長期間の時間ス ケール、広い空間スケールでの評価結果の検証が必要で ある.また、今回の河川環境改善実験方法では、落葉を 捕捉しやすくするような比較的簡単な工夫で有機物を滞 留させ早瀬の河川環境を改善できたが、実用的、具体的 な工法への適用、淵の改善方法も考えていきたい。

謝辞 : 本研究は北海道開発局から受託研究による補助を 受けた。また、調査、分析方法について北海道立水産卯孚 化場中島美由紀氏、卜部浩一氏、和光技研中原修氏、布 川雅典氏にご指導いただいた。ここに記して謝意を表す。

\section{参考文献}

1)谷田一三: 生態学的視点による河川の自然復元一生態的循 環と連続性について、応用生態工学 2(1)、pp37-45、1999

2)玉井信行、奥田重俊、中村俊六 : 河川生態環境評価法、東 京大学出版会、2000

3)土屋十蓉、平井正風、風間真理 : 山地河川における河床環 境と底生動物の変化に関する研究、水工学論文集第 46 巻、 pp1235-1240、2002

4)風間真理、土屋十官、平井正風 : 河川改修や洪水の㩇乱が ベントスに与える影響とその評価に関する研究、河川技術論文 集第 6 巻、pp107-112、2000

5)大杉奉功、福田圭一、泉田武宏 : 夕゙ムの試験湛水時におけ る流況変動と底生動物群集の応答関係に関する研究、河川技術 論文集第 6 巻、pp179-184、2000

6) 長坂晶子、中島美由紀、柳井清治、長坂有 : 河床の砂碟 構成が底生動物の生息環境に及ぼす影響一、応用生態工学 3(2)、 pp243-254、2000

7) Junjiro N.Negishi,John S.Richardson : Responses of organic matter and macroinvertebrates to placements of boulder clusters in a small stream of southwestem british columbia,

Canada,Can.J.Fish.Aquat.Sci.60:pp247-258、2003

8) 布川雅典 井上幹生 : 北海道北部の小河川における河畔 植生と水生昆虫群集との対応様式、陸水学雑誌 60、pp385-397、 1999

(2004.9.30 受付) 